\title{
POMC Gene
}

National Cancer Institute

\section{Source}

National Cancer Institute. POMC Gene. NCI Thesaurus. Code C38178.

This gene is involved in several diverse cellular functions. 